Acta Theriologica 42 (2): 123-141, 1997.

PL ISSN 0001-7051

\title{
Airborne and substrate-borne communications of Microtus (Terricola) gerbei and M. (T.) duodecimcostatus
}

\author{
Stella M. GIANNONI*, Rafael MÁRQUEZ and Carlos E. BORGHI*
}

Giannoni S. M., Márquez R. and Borghi C. E. 1997. Airborne and substrate-borne communications of Microtus (Terricola) gerbei and $M$. (T.) duodecimcostatus. Acta Theriologica 42: 123-141.

The repertoire of airborne and substrate-borne communications is described for two species of mole-voles: Microtus (Terricola) gerbei (de Sélys-Longchamps, 1847) and M. (T.) duodecimcostatus (de Sélys-Longchamps, 1839). The behavioural significance of the different types of sounds emitted was analysed from observations of intraspecific interactions in captive environments. Substrate-borne signals were used more often by dominant individuals, and were predominantly recorded in the more aggressive species, $M$. duodecimcostatus. The use of substrate-borne signals is much more prevalent in the more aggressive $M$. duodecimcostatus, while the less aggressive $M$. gerbei has a larger acoustical repertoire.

Instituto Pirenaico de Ecología, CSIC, Apartado 64, 22700 Jaca Huesca, Spain (SMG, CEB); Departamento Biología Evolutiva, Museo Nacional de Ciencias Naturales, 28006 Madrid, Spain (RM)

Key words: blind mole-voles, Microtus (Terricola) gerbei, M. (T.) duodecimcostatus, sounds, acoustic communication

\section{Introduction}

Subterranean mammals show diverse degrees of atrophy of the eyes and sight while the organs involved in olfactory and acoustical communications may show hypertrophy (Quilliam 1966, Nevo 1979). Reichman and Smith (1990) considered that typical modes of mammalian communication, such as visual and olfactory signals, were probably ineffective for subterranean species, many of which have evolved alternative modes of communication. However, Nevo (1990), Nevo et al. (1976) and Heth and Todrank (1995) found that odour is very effective and important in Spalax ehrenbergi.

The possible use of substrate-borne vibrations in communication appears to be rather common for a wide variety of fossorial and subterranean vertebrates. This has been described for reptiles (Hartline 1971, Hetherington 1992), amphibians (Dimmint and Ruibal 1980, Lewis and Narins 1985), and for rodents such as

\footnotetext{
* Present address: Unidad de Zoología y Ecología Animal, IADIZA-CRICYT, Casilla de Correo 507, 5500 Mendoza, Argentina
} 
Dipodomys spectabilis (Randall 1984), Spalax ehrenbergi (Heth et al. 1987, 1988, 1991, Nevo et al. 1987, 1991, Rado et al. 1987, 1989, 1991) and bathyergid mole-rats (Bennett and Jarvis 1988).

Burda et al. (1990) and Hetherington (1992) suggest that information on the modes of communication of fossorial and subterranean animals is scanty, and only recent studies have started to address this interesting issue. The vocal repertoire of a few fossorial or subterranean species of rodents has been described: Spalacopus cyanus (Eisenberg 1974), Spalax ehrenbergi (Capranica et al. 1973, Nevo et al. 1987, Heth et al. 1988, Nevo 1990), and Heterocephalus glaber (Pepper et al. 1991). Substrate-borne communication, a different and typical means of communication of this underground ecotope, has been thoroughly studied in Spalax (Heth et al. 1987, 1991, Rado et al. 1987, 1989, 1991, Nevo et al. 1991), and Cryptomys damarensis (Bennett and Jarvis 1988).

Airborne communication in fossorial and subterranean rodents appears to be related to the reproductive behaviour, to short range interactions between animals in solitary species (Nevo 1969, Capranica et al. 1973, Nevo et al. 1987, Heth et al. 1988, Rado et al. 1991), and to some social interactions in highly social species (Burda et al. 1990, Pepper et al. 1991). This type of communication requires the individuals to be in close proximity (less than ca $5 \mathrm{~m}$ apart; Heth et al. 1987). On the other hand, substrate-borne signals appear to be most effective at longer ranges as it has been reported for fossorial and subterranean rodents: Dipodomys spectabilis (Randall 1984, 1994), Spalax ehrenbergi (Heth et al. 1987, 1991, Rado et al. 1987, 1991, Nevo et al. 1991), Georychus capensis, Bathyergus suillus and B. janetta (Jarvis and Bennett 1991), where one of the functions of seismic signals may be territorial warning.

We compared two closely related, sympatric species of blind mole-voles of the subgenus Terricola: the Pyrenean blind mole-vole Microtus (Terricola) gerbei (de Sélys-Longchamps, 1847) and the Mediterranean blind mole-vole $M$. (T.) duodecimcostatus (de Sélys-Longchamps, 1839). Formerly, both the New World and the Old World species of the genus Microtus were placed in the subgenus Pitymys. Currently, $M$. gerbei and $M$. duodecimcostatus are recognized as belonging to the subgenus Terricola (Chaline et al. 1988), which contains an additional 11 species (Wilson and Reader 1993).

Species of the subgenus Terricola have distinctive features among the Arvicolinae. Unlike species of the subgenus Pitymys, they are ecologically, behaviourally, morphologically and physiologically well-adapted to subterranean life. The vernacular name in Spanish, Topillos, means small mole. They build complex burrow systems with several holes and mounds from excavated dirt, and maintain closed burrow systems (Vericad 1970, Soriguer and Amat 1980, Borghi 1992, Giannoni 1994, Martínez-Rica et al. 1995). Martínez-Rica et al. (1995) found that the mean diameter of mounds is $15.66 \mathrm{~cm}(\mathrm{SD}=5.61)$, mean height is $7.30 \pm 2.41 \mathrm{~cm}$, the mean angle of entrance tunnels is $51.85 \pm 22.59 \mathrm{~cm}$, and the mean diameter of entrance tunnels is $3.11 \pm 0.64 \mathrm{~cm}$. The body is cylindrical; with reduced tail, 
limbs, eyes, and ears (Agrawal 1967, Mathias 1991, Giannoni 1994, Borghi et al. 1997). Also, as other fossorial mammals, they have a blood buffering high capacity under hypoxic-hypercapnic stress (Mathias 1989, 1990, 1991, Mathias and Freitas 1989, Pérez-Suárez et al. 1990). Additionally, they have a long lifespan in natural conditions (Paradis and Guédon 1993), relatively low reproductive rates (Stérba et al. 1986, Guédon et al. 1992, Paradis and Guédon 1993), a small litter size (Guédon et al. 1991a, b), and a sex ratio near 1:1 (Paradis and Guédon 1993). They live in social groups of different sizes (Soriguer 1990, Borghi 1992), with high social integration (Salvioni 1988, Giannoni 1994), and lead an almost completely subterranean existence (Vericad 1970, Mathias 1989, 1991). Their diet consists mostly of geophyte storage organs and subterranean portions of herbaceous plants (Borghi et al. 1997).

Microtus (Terricola) duodecimcostatus (average weight $\pm \mathrm{SD}=19.0 \pm 2.4 \mathrm{~g}$, $n=26$ ), and $M$. (T.) gerbei ( $20.7 \pm 1.6 \mathrm{~g}, n=9$ ) occur sympatrically in the Spanish Pyrenean Mountains (Vericad 1970, Borghi et al. 1991, Borghi 1992). These species differ in the degree of sociability and aggressiveness exhibited. $M$. gerbei occurs in social groups of 5-16 individuals, and shows low levels of aggressiveness in interactions involving individuals of the same or of different social groups (Borghi 1992, Giannoni 1994). In contrast, $M$. duodecimcostatus is monogamous (Soriguer 1990, Paradis and Guédon 1995), only one pair, or one pair with two litters, occurring in each burrow system (R. Soriguer, pers. comm.). Interactions between members of different groups exhibit high levels of aggressiveness (Giannoni 1994).

In this paper we intend to contribute to the knowledge of communication systems of the subgenus Terricola by describing and comparing airborne and substrate-borne sounds for two species of subterranean rodents: Microtus (Terricola) duodecimcostatus and $M$. (T.) gerbei. Their vocal and substrate-borne sound repertoire is studied in relation to other behavioural patterns.

\section{Material and methods}

The animals were captured in 1991-1992 in the Aisa Valley at $2000 \mathrm{~m}$ a.s.l. in the Spanish Pyrenean Mountains with Sherman-like traps. Setting these traps involves digging burrow openings until the deeper tunnels are found. The traps are then inserted in the exposed portion of the burrow, about $25 \mathrm{~cm}$ deep, on a level with the burrow floor. The capture site, sex, weight, and age of all individuals trapped were recorded. All observations were made on adult individuals sexually inactive. Mole-voles weighing over $14 \mathrm{~g}$ were classified as adults (Borghi 1992). Animals were kept in individual cages of $26 \times 13 \times 25 \mathrm{~cm}$. The floor of every cage was covered with earth, and each of them was provided with nest-building material and food ad libitum (carrots and peanuts). All individuals were maintained under photoperiod of $14 \mathrm{~h}$ light: $10 \mathrm{~h}$ dark, at temperature of $23 \pm 1^{\circ} \mathrm{C}$.

A total of $24 M$. (T.) gerbei (15 females, 9 males) and $29 M$. (T.) duodecimcostatus (16 females, 13 males) were tested in 94 intraspecific agonistic pair-encounters. All pairs of the same species were randomly selected: 45 intraspecific pairs of $M$. (T.) gerbei $(22$ encounters female-female, 13 female-male, 10 male-male), and 49 intraspecific pairs of $M$. (T.) duodecimcostatus (18 encounters female-female, 14 female-male, 17 male-male). The minimum time between tests for each animal was $48 \mathrm{~h}$. In addition, 10 single animals ( 5 of each species) were observed and recorded for 5 minutes while 
disturbed by human intervention. Being blind, mole-voles were disturbed by being lightly touched with a wooden stick or a similar object. This type of disturbance was used in an attempt to learn whether these species, when disturbed, are likely to emit sounds other than those recorded in pair-encounters. Total observations and recordings lasted 470 minutes, each interaction and each single animal were recorded for 5 minutes. Data were collected at night $(21.00-23.00 \mathrm{~h})$ because this is usually the less noisy time.

The device used consisted of two plastic chambers $(26 \times 13 \times 25 \mathrm{~cm})$, covered by two sheets of transparent plastic, and connected by a glass tube $(60 \times 11 \times 8 \mathrm{~cm})$. The tube had two gates, one at each end. Each individual was placed in a plastic chamber with the gates closed for acclimatization, and 5 minutes later the gates were opened, and substrate-borne signals were recorded for the duration of the intraspecific encounters (5 minutes). Substrate-borne signals occur in the tube when the animal advances towards its opponents chamber, and consist of evident incisor strikes against the substrate. Hence, in order to record these signals, and at the same time prevent the interference of echo, the microphone was placed halfway on the external surface of the tube. On the other hand, vocal sounds were recorded in a plastic container $(50 \times 50 \times 25 \mathrm{~cm})$ floored with cotton to diminish the interference of other noises (ie from nails); in this case the microphone was held by the observer approximately $10 \mathrm{~cm}$ away from the animals.

All signals were recorded with a TCM-5000 EV Sony cassette tape recorder and a microphone ATR55 Telemike. Recordings were digitized with Sound Tools (sampling frequency $44.1 \mathrm{kHz}$ ) and analysed in an Apple Macintosh computer. A characteristic portion of recording was used to depict each type of sound and to obtain numerical information about the temporal and spectral features of the calls. Signallized software was used for sound analyses and for the production of audiospectrograms, spectrograms, and oscillograms. The equipment used for sound recording and analysis limited the frequencies to the acoustic range $(40-17,000 \mathrm{~Hz})$. Therefore any ultrasonic or other signals beyond this range were not included in this study. Each type of sound recorded was associated with the behaviour of the animal when emitted, and with the type of encounter (aggressive or non-aggressive) by contingency table analyses (Zar 1984).

Interactions were classified as aggressive or non-aggressive. An interaction was considered aggressive when one or both animals showed: biting, chasing, lunging, roll-over-fight or threat (Clarke 1956, Montgomery 1978, Giannoni 1994). Non-aggressive interactions included amicable or avoidance encounters. When none of the animals showed aggressive acts the encounters were scored as non-aggressive, those encounters were classified as avoidance or as amicable. Avoidance interactions were defined when one animal positioned itself as far as possible from the other in the device and remained relatively immobile during the 5-min encounter (Colvin 1973). Amicable interactions were those involving behaviours usually considered friendly. These included: mutual grooming, crawling under (Montgomery 1978), lying over, and sitting together (Ferkin and Rutka 1990). We also recorded which animal was dominant. Dominance status was established based on which individual showed more of the aggressive behaviours defined above (active dominance; Hand 1986), as well as on which animal was less inhibited in its movements within the testing arena (passive dominance; Hand 1986). As suggested by Eisenberg (1968), Kruuk (1972), Colvin (1973), Hinde and Stevenson-Hinde (1976), and Cranford and Derting (1983) the expression of superior status may not depend on aggression but be exhibited through freer movement, grooming or other activities within a given area, while the subordinate individual withdraws and shows little movement. The trials where the outcome of encounters was unclear were excluded from the analysis: 8 for $M$. gerbei and 3 for $M$. duodecimcostatus.

\section{Results}

The repertoire of the animals included both vocal and non-vocal sounds. Vocal sounds present an obviously tuned structure (where the sound energy is con- 
centrated on one or only a few frequencies), suggesting vocal cords involvement in its production. A vocal component in some sounds was found in addition to spectrally complex noisy sounds, possibly produced by friction of inhaled or exhaled air. These calls were also considered to be vocal sounds. Non-vocal sounds are probably produced without using the vocal cords and include fricative and occlusive sounds, and those caused by mechanical tapping. In general they lacked a simple spectral structure, thus being more interesting in a temporal setting.

\section{Microtus (Terricola) gerbei}

This species produces four groups of vocal sounds (greeting sounds, amicable, distress, and tapping), and three non-vocal sounds (throat rasping, tooth grinding, and substrate-borne signals), although throat rasping, observed only once, proves extremely rare.

\section{Vocal sounds}

Greeting sounds. These sounds (Fig. 1a) have variable durations (range $122-147 \mathrm{~ms}, \mathrm{ME}=81.4 \mathrm{~ms}, \mathrm{SD}=21.45, n=7$ ), and present spectral features similar to the distress sounds. The fundamental frequency of the tonal component was found to be about $1800 \mathrm{~Hz}(\mathrm{ME}=1724.4 \mathrm{~Hz}, \mathrm{SD}=81.87$, range 1615-1838 $\mathrm{Hz}, n=5$ ), the dominant frequency often being the third harmonic. These sounds, having low intensity, were produced when one animal advanced, sniffed and crouched towards the other individual. This sound caused the second animal to sniff and approach the animal emitting greeting sounds. Subsequently both animals mutually sniffed each other's nose and body.

Amicable sounds (Fig. 1b). The duration of these notes was rather variable though three different duration classes were discernible: short (range 17-32 ms, $\mathrm{ME}=27 \mathrm{~ms}, n=7$ ), medium (range $40-71 \mathrm{~ms}, \mathrm{ME}=56 \mathrm{~ms}, n=13$ ), and long (range $84-95 \mathrm{~ms}, \mathrm{ME}=90 \mathrm{~ms}, n=3$ ). The dominant frequency was about $1900-2000 \mathrm{~Hz}$ (range 1776-2261 Hz, ME $=1923.32 \mathrm{~Hz}, \mathrm{SD}=149.91, n=12$ ). Power was also present in the second and third harmonics. These vocalizations present spectral characteristics similar to the preceding ones. They are emitted at close range only and lack much intensity. These sounds were made when one animal crawled under the other (often in the corner of the chamber) or when one nibbled the hair on the head, ear, neck and shoulders of the other.

Distress sounds. Included short notes (duration: $43.14 \mathrm{~ms}$, range $35-49 \mathrm{~ms}$, $\mathrm{SD}=5.76, n=7$ ), and longer notes (96.4 ms, range 87-113 $\mathrm{ms}, \mathrm{SD}=10.43, n=$ 5 ). The notes could be simple bursts of noise without clear spectral peaks or contain more tuned tonal sounds with complex frequency modulation patterns (Fig. 2a). The fundamental call frequency was found to be about $1900 \mathrm{~Hz}$. The dominant frequency was most commonly the third harmonic (range 5,432-5,775 Hz, 

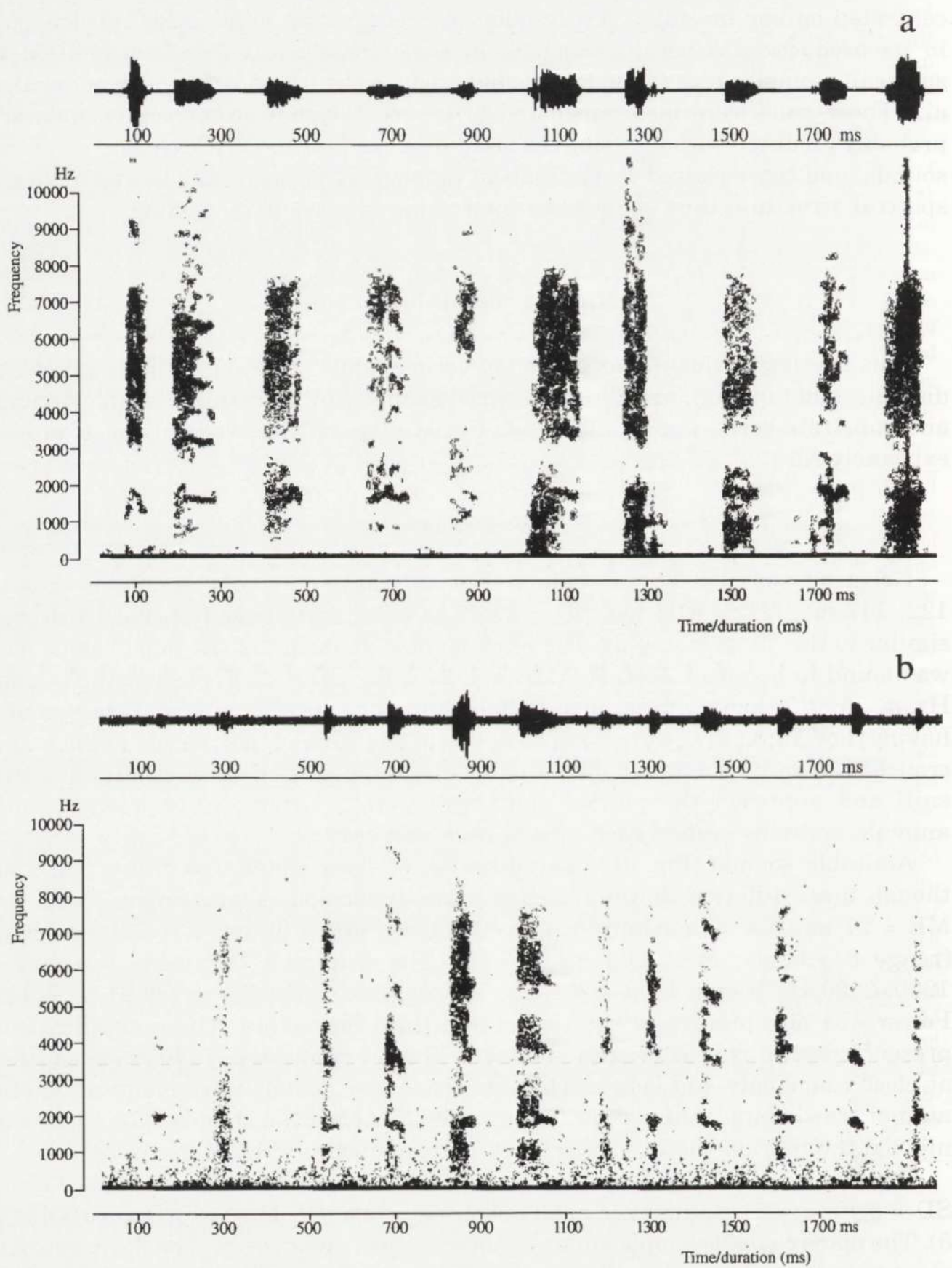

Fig. 1. Oscillogram and audiospectrogram of a 2-second recording of greeting sounds (a) and amicable sounds (b) of Microtus (Terricola) gerbei. 

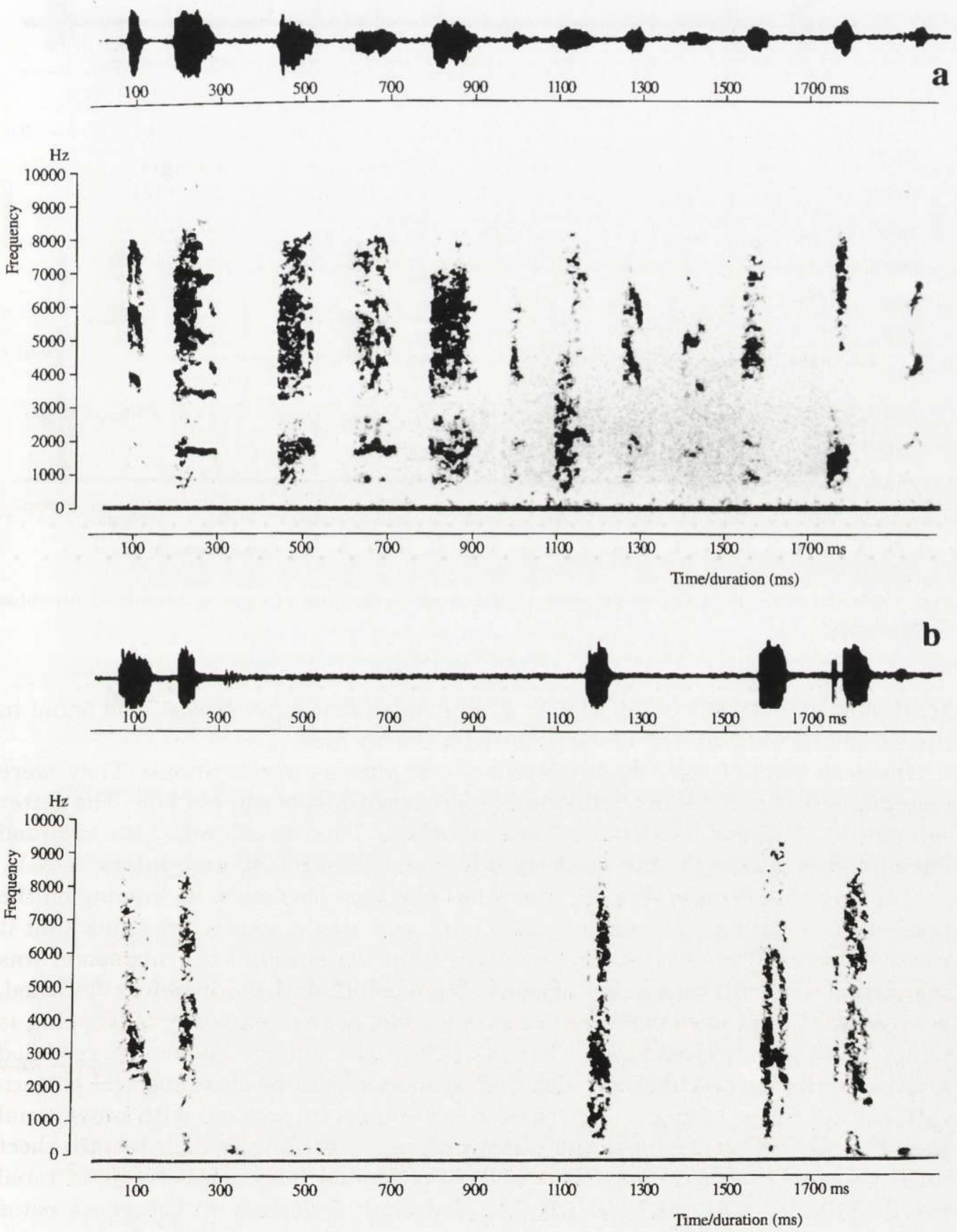

Fig. 2. Oscillogram and audiospectrogram of a 2-second recording of distress sounds of Microtus (Terricola) gerbei (a) and M. (T.) duodecimcostatus (b). 

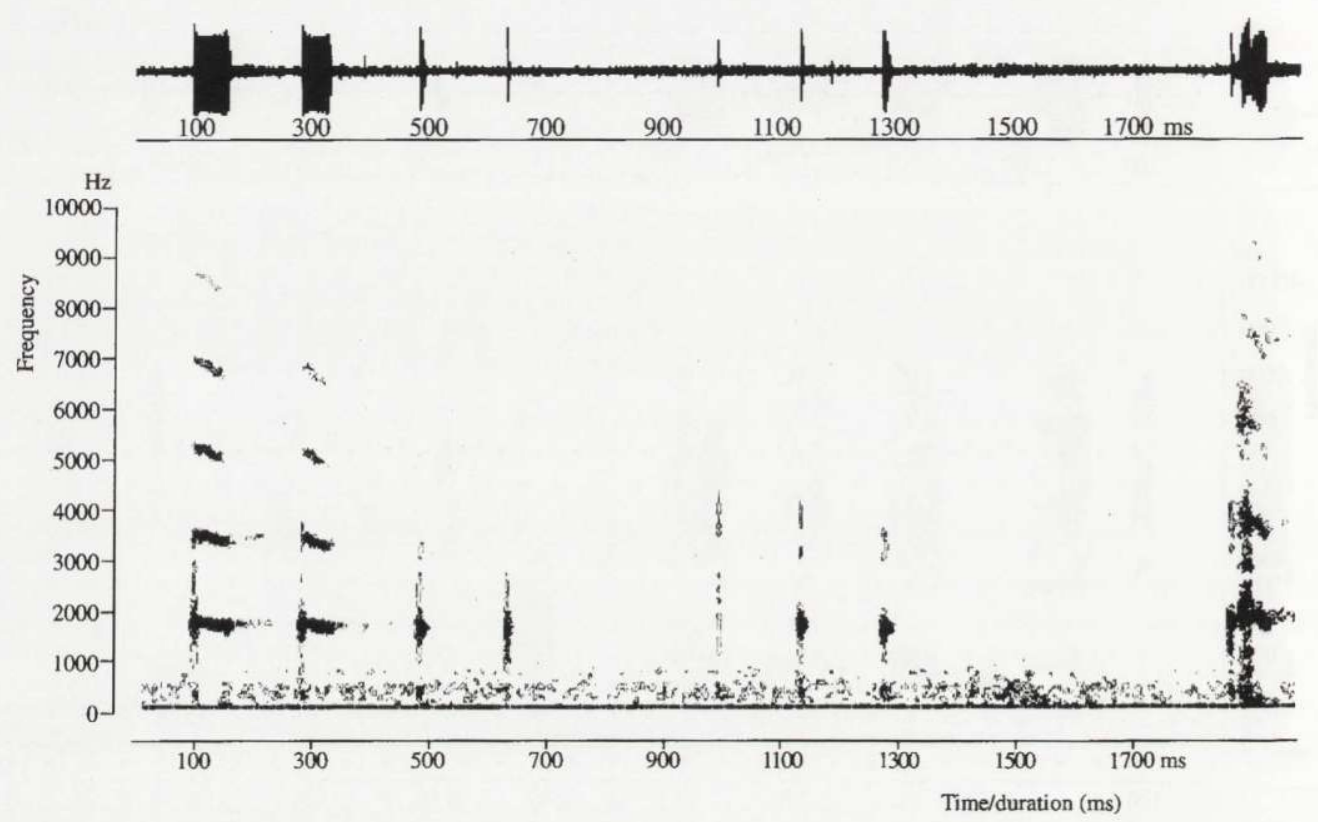

Fig. 3. Oscillogram and audiospectrogram of a 2-second recording of tapping sounds of Microtus (Terricola) gerbei.

$\mathrm{ME}=5,648.75 \mathrm{~Hz}, \mathrm{SD}=150.35, n=4)$ while significant power was also found in the second $(3,800 \mathrm{~Hz})$ and fourth $(3,600 \mathrm{~Hz})$ harmonics.

Distress sounds were highly-intense, conspicuous vocalizations. They were recorded when a dominant individual approached a subordinate one. The latter screamed, remained motionless, and crouched. This sound was also recorded during fights, although this was very infrequent ( 2 of the 45 encounters; $4.4 \%$ ).

Tapping. A soft noise (Fig. 3), somewhat like the noise made by tapping on the hard surface. Although it was recorded once in a single animal, we think that it was easy to miss because of its low intensity in the encounters. This sound was only associated with human disturbance. When emitted, the animal was crouched, bent forward, and open-mouthed, in an alert but not scared position. Tapping is composed of two different types of sounds: noisy ticks and tonal notes. We recorded a large number of mechanical noisy ticking sounds with no clear spectral pattern $(\mathrm{ME}=2.14, \mathrm{SD}=1.52, n=24)$. These tonal sounds intermixed with other tonal sounds, could be grouped into two distinct classes according to their length: short tonal notes $(\mathrm{ME}=13.39 \mathrm{~ms}, \mathrm{SD}=7.85, n=23)$, and longer, less frequent tonal notes $(69.92 \pm 15.51 \mathrm{~ms}, n=13)$. The dominant frequency of the short notes $(\mathrm{ME}=1,649.61 \mathrm{~Hz}, \mathrm{SD}=68.25, n=23)$ was lower than that of the longer notes $(1,735.15 \pm 60.25 \mathrm{~Hz}, n=13$; Mann Whitney $U$-test, $p<0.001)$. 
a
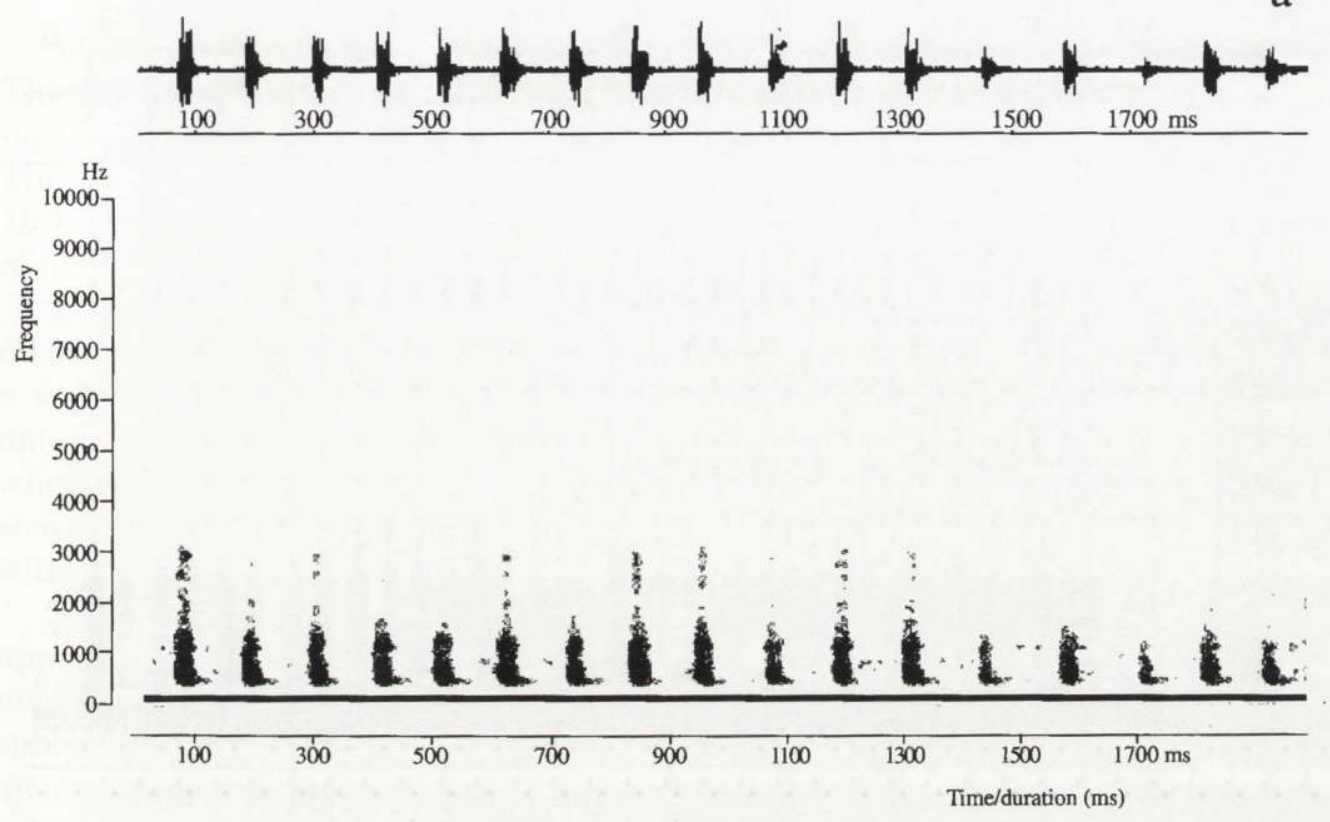

b

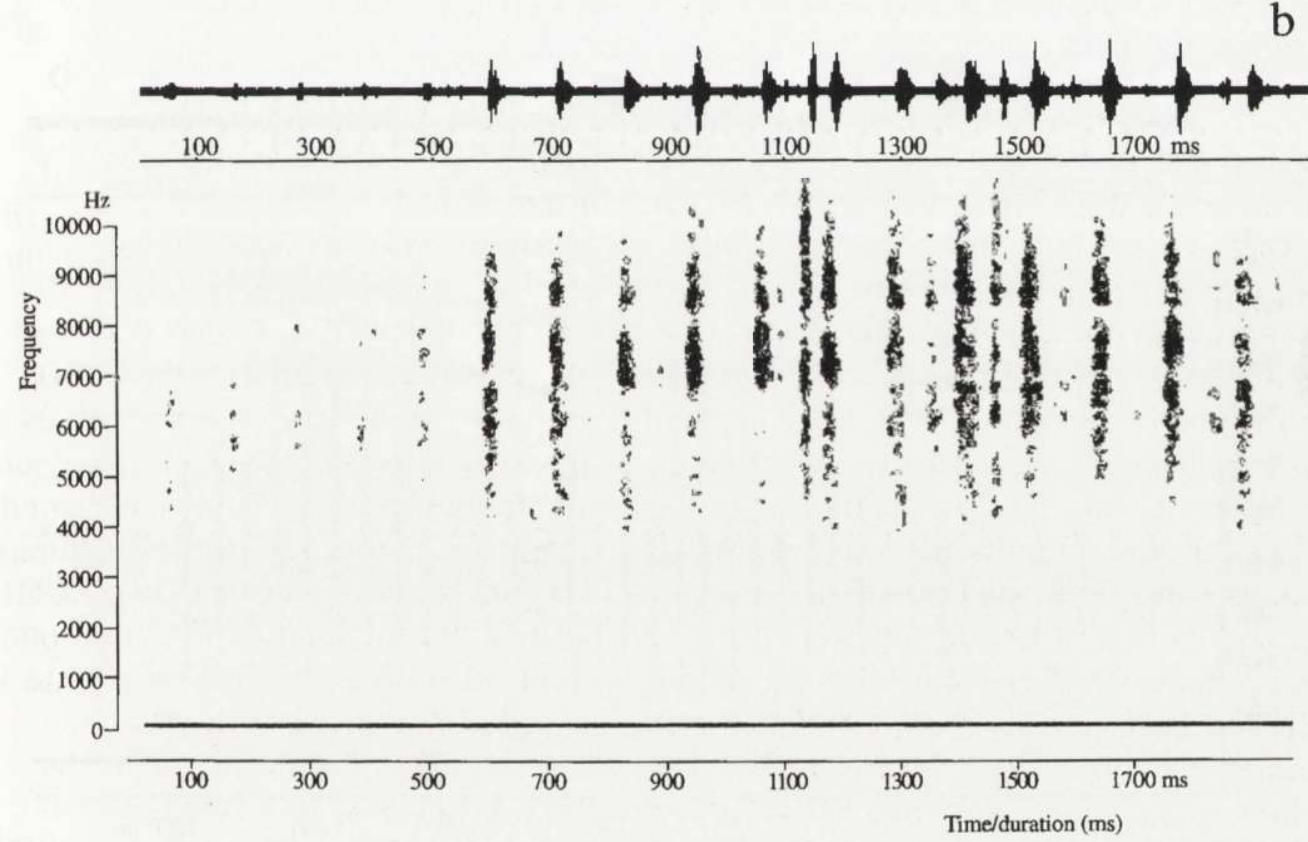

Fig. 4. Oscillogram and audiospectrogram of a 2-second recording of throat rasping sounds of Microtus (Terricola) gerbei (a) and M. (T.) duodecimcostatus (b). 

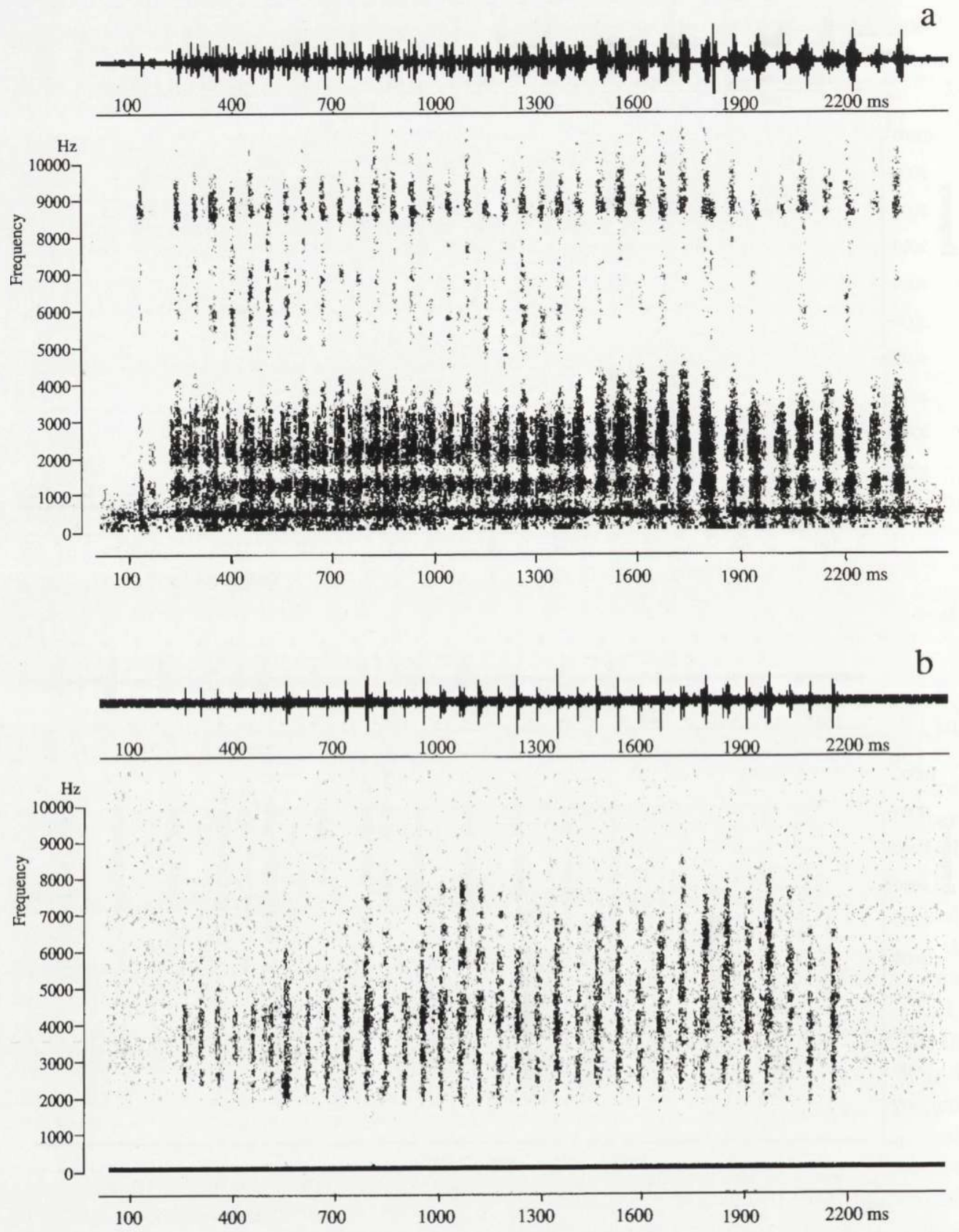

Fig. 5. Oscillogram and audiospectrogram of a 2.5-second recording of tooth grinding sounds of Microtus (Terricola) gerbei (a) and M. (T.) duodecimcostatus (b). 
Non-vocal sounds/signals

Throat rasping. Only recorded once, and associated with human disturbance. This sound (Fig. 4a) appears to be a harmonically-complex sequence of regularly-spaced sound bursts with power in the lower end of the spectrum $(500-1,500 \mathrm{~Hz})$. The interval of sound emission is highly regular $(\mathrm{ME}$ interval $=62.649, \mathrm{SD}=$ $15.787, n=131$ bursts, 4 pulse trains). The animal produced the sound with its mouth gaping and bending forward.

Tooth grinding. A train of 25-55 pulses regularly emitted at mean intervals of $60.581 \mathrm{~ms}(\mathrm{SD}=9.098$, minimum interval $=43 \mathrm{~ms}$, maximum interval $=84 \mathrm{~ms}$, $n=4$ pulse trains, 124 pulses; Fig. $5 \mathrm{a}$ ). Tooth grinding is a scraping or chattering noise produced by rubbing together the upper and lower incisors. It was produced when a subordinate individual started to approach the dominant animal. The sound was emitted when the dominant animal was hunched up (all 4 feet on floor) with shoulder hairs erect.

Substrate-borne signals. Produced by striking the floor of the tunnel with the upper incisors (seismic drumming). Substrate-borne signals was associated with investigation, sniffing and approaching of a dominant individual towards a subordinate. The signal resulting from the rather arrhythmic beating of the incisors against the substratum was a train of pulses regularly emitted at mean intervals of $139 \mathrm{~ms}$ (range $105-196 \mathrm{~ms}, \mathrm{SD}=49.22, n=1$ pulse trains, 4 pulses; Fig. 6a).

\section{Microtus (Terricola) duodecimcostatus}

In this species only one type of vocal sound was found (distress sounds), whereas three types of non-vocal sounds/signals (throat rasping, tooth grinding, and substrate-borne signals) described for $M$. (T.) gerbei were found.

\section{Vocal sounds}

Distress sounds. Including mainly long notes (duration: range $46-127 \mathrm{~ms}, \mathrm{ME}$ $=79.5 \mathrm{~ms}, \mathrm{SD}=27, n=12.37$ ). The notes were bursts of noise usually containing more tuned vocal sounds with complex frequency modulation patterns often in the shape of a chevron with a longer down sweep arm (Fig. 2b). The fundamental frequency of the calls ranged from 1800 to $2300 \mathrm{~Hz}$ (range 1,373-2,645 Hz, $\mathrm{ME}=2090.73 \mathrm{~Hz}, \mathrm{SD}=359.68, n=15$ ). Substantial power was also found at $6500 \mathrm{~Hz}$. Distress sounds were produced in a behavioural context similar to that of $M$. (T.) gerbei.

$$
\text { Non-vocal sounds/signals }
$$

Throat rasping. Produced in this species in a behavioural context and posture similar to those of the Pyrenean blind-vole. This sound (Fig. 4b) was a sequence of regularly-spaced noise bursts with power in the higher end of the spectrum (from 4,500 to above $10,000 \mathrm{~Hz}$ ). The duration of the bursts was variable (duration: range $6-41 \mathrm{~ms}, \mathrm{ME}=23.765 \mathrm{~ms}, \mathrm{SD}=10.42, n=17)$. The interval of sound 

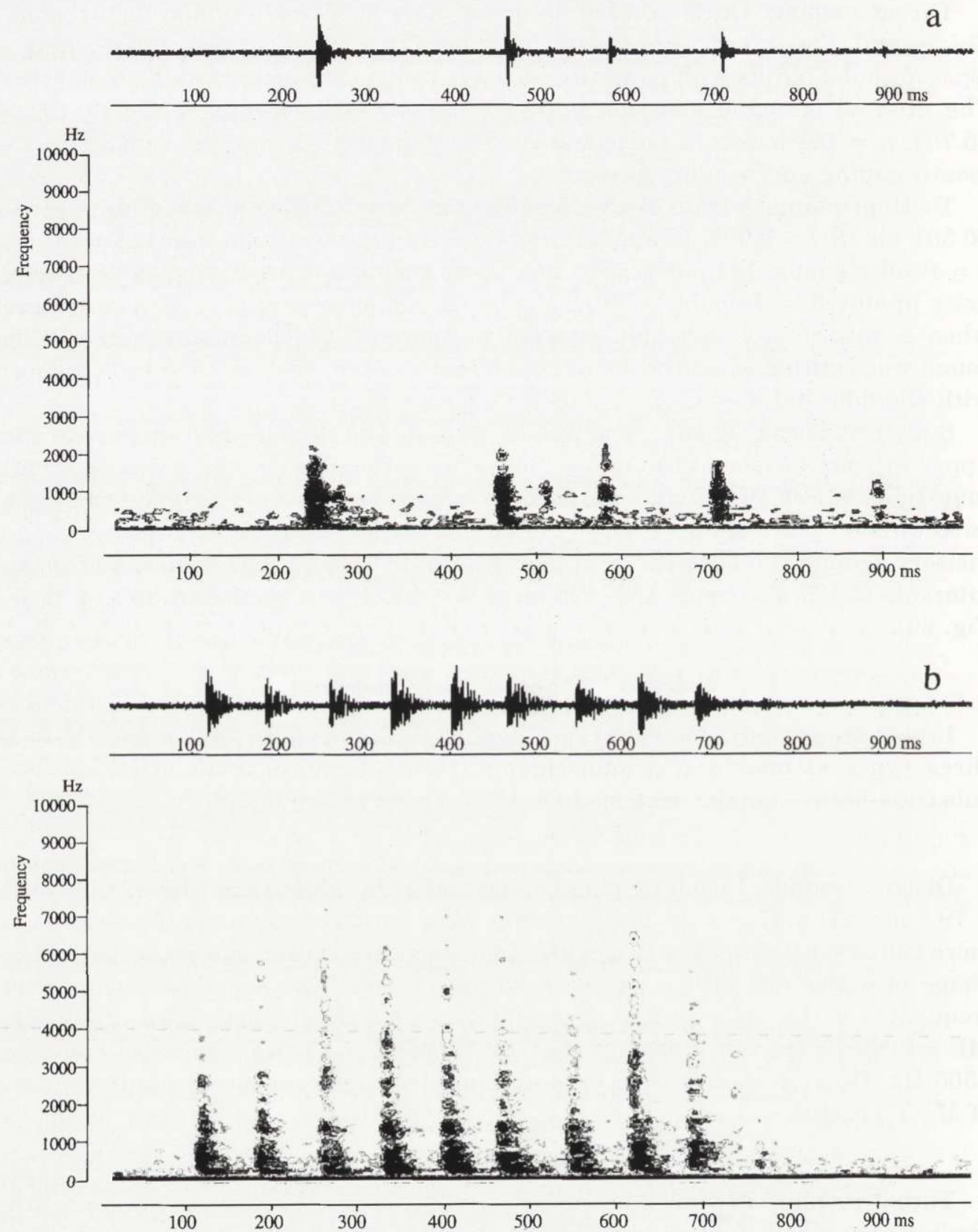

Fig. 6. Oscillogram and audiospectrogram of a 2-second recording of seismic drumming sounds of Microtus (Terricola) gerbei (a) and $M$. (T.) duodecimcostatus (b). 
emission was quite regular $(\mathrm{ME}$ interval $=76.076 \mathrm{~ms}, \mathrm{SD}=25.102$, minimum interval $=18 \mathrm{~ms}$, maximum interval $=101 \mathrm{~ms}, n=17$ pulses $)$.

Tooth grinding. Emitted at close range by dominant individuals (see analyses below). The sound was produced in a behavioural context similar to that of $M$. (T.) gerbei and with identical body posture. The resulting sound (Fig. $5 \mathrm{~b}$ ) is a train of pulses regularly emitted at mean intervals of $56.33 \mathrm{~ms}$ (range $31-71 \mathrm{~ms}$, $\mathrm{SD}=8.13, n=6$ pulse trains, 156 pulses from three individuals).

Substrate-borne signals. This noise was emitted like in $M$. (T.) gerbei, by striking the floor of the tunnel with the upper incisors, and under circumstances similar to those of the Pyrenean blind-vole. However, it was observed much more frequently (57\% of the encounters), and it included a much higher number of drumming bouts (Fig. 6b). It was a train of pulses regularly emitted at mean intervals of $36.44 \mathrm{~ms}$ (range $27-44 \mathrm{~ms}, \mathrm{SD}=5.247, n=1$ pulse trains, 9 pulses).

\section{Behavioural significance of sounds and signals}

Only the results recorded during observations of intraspecific encounters were quantified, since animals kept isolated rarely emitted any sounds. In $M$. (T.) gerbei, tooth grinding was recorded in 18 encounters (40\%) out of a total of 45 intraspecific encounters. In considering only intersexual encounters, tooth grinding was found to be significantly more frequent in males (11 of 13 encounters, $85 \% ; \chi^{2}$-test, $p<0.05$ ). Substrate-borne signals were only recorded in 6 of the total intersexual encounters (ie 13\%). No significant differences were found between the frequency of emission of substrate-borne signals in both sexes $\left(\chi^{2}\right.$-test, $\left.p>0.05\right)$, since 4 females $(67 \%)$ and 2 males (33\%) emitted these sounds in the total 13 intersexual encounters. In $M$. (T.) duodecimcostatus, tooth grinding was recorded in 26 encounters $(53 \%)$ out of a total of 49 intraspecific encounters, and 28 included substrate-borne signals $(57 \%)$. In the 14 intersexual encounters considered, no significant trends of the emitter were found to be associated with sex either in substrate-borne signals: $57 \%$ of females and $43 \%$ of males emitted these sounds $\left(\chi^{2}\right.$-test, $\left.p>0.05\right)$, or in tooth grinding: $58 \%$ of females and $42 \%$ of males emitted these sounds $\left(\chi^{2}\right.$-test, $\left.p>0.05\right)$.

The frequency of emission of tooth grinding was not significantly different between the two species $[M$. (T.) gerbei $=40 \%$ of 45 encounters, and $M$. (T.) duodecimcostatus $=53 \%$ of 49 encounters; test for difference between proportions: $\mathrm{Z}=0.678$, g.l. $=2, p>0.05 ;$ Zar 1984]. On the other hand, $M$. (T.) duodecimcostatus emitted significantly more substrate-borne signals than $M$. (T.) gerbei $[M$. (T.) duodecimcostatus $=57 \%$ of 49 encounters, and $M$. (T.) gerbei $=13 \%$ of 45 encounters; $\mathrm{Z}=5.30$, g.l. $=2, p>0.05]$. Finally, the occurrence of emissions of distress sounds was not found to be significantly different between species. $M$. (T.) gerbei emitted these sounds in $60 \%$ of the encounters and $M$. (T.) duodecimcostatus in $75 \%$ $(\mathrm{Z}=1.774$, g.l. $=2, p>0.05)$. A high proportion of dominant individuals produced both tooth grinding and substrate-borne signals in both species (Table 1). The individuals emitting distress sounds were predominantly subordinate and the 
Table 1. Frequency of emission of tonal and non-tonal sounds in intraspecific encounters of Microtus (Terricola) gerbei and $M$. (T.) duodecimcostatus, in relation to the dominant or subordinate status of the animal emitting the sound. Probability values comparing equiprobability of emission by dominant and subordinate individuals are determined by $\chi^{2}$-tests $\left({ }^{1}\right.$ except for distress sounds in $M$. (T.) gerbei where we use the Fisher-test because there are two cells with expected frequency less then 5; Siegel 1986).

\begin{tabular}{|c|c|c|c|c|c|c|}
\hline & \multicolumn{2}{|c|}{$\begin{array}{l}\text { Tooth } \\
\text { grinding }\end{array}$} & \multicolumn{2}{|c|}{$\begin{array}{l}\text { Distress } \\
\text { sounds }\end{array}$} & \multicolumn{2}{|c|}{$\begin{array}{c}\text { Substrate } \\
\text { borne-signals }\end{array}$} \\
\hline & Yes & No & Yes & No & Yes & No \\
\hline \multicolumn{7}{|c|}{$M$. ( $T$. .) gerbei (37 interaction considered) } \\
\hline Dominant & 14 & 23 & 6 & 31 & 6 & 31 \\
\hline \multirow[t]{2}{*}{ Subordinate } & 4 & 33 & 17 & 20 & 0 & 37 \\
\hline & \multicolumn{2}{|c|}{$p<0.01$} & \multicolumn{2}{|c|}{$p<0.01^{1}$} & \multicolumn{2}{|c|}{$p<0.05$} \\
\hline \multicolumn{7}{|c|}{$M .(T$.$) duodecimcostatus (42 interaction considered)$} \\
\hline Dominant & 30 & 12 & 17 & 25 & 33 & 9 \\
\hline \multirow[t]{2}{*}{ Subordinate } & 6 & 36 & 38 & 4 & 13 & 29 \\
\hline & \multicolumn{2}{|c|}{$p<0.01$} & \multicolumn{2}{|c|}{$p<0.001$} & \multicolumn{2}{|c|}{$p<0.001$} \\
\hline
\end{tabular}

relationship between the emission of the different types of sounds and dominance status was highly significant (see Table 1). The intraspecific encounters of $M$. (T.) gerbei were significantly less aggressive than those of $M$. (T.) duodecimcostatus, only $13 \%$ of the encounters were aggressive in $M$. (T.) gerbei while $69 \%$ of all the interactions were aggressive in $M$. (T.) duodecimcostatus (difference between proportions, $t$-test, $p<0.0001$ ).

For $M$. (T.) duodecimcostatus, we found no significant differences in aggressiveness between sexes in intersexual encounters $\left(\chi^{2}\right.$-test, $\left.p>0.05\right)$, but in $M$. (T.) gerbei, males were more aggressive than females $\left(\chi^{2}\right.$-test, $\left.p<0.05\right)$.

\section{Discussion}

The frequency ranges we observed in the vocal sounds produced by the blind mole-voles suggest that considerable energy is contained between $1000 \mathrm{~Hz}$ and $5000 \mathrm{~Hz}$. With the exception of throat rasping in $M$. (T.) gerbei, and substrate-borne signals in both species, the dominant frequencies of the sounds produced are far from the optimum frequency for transmission in mole-rat burrows $(440 \mathrm{~Hz})$ according to Heth et al. (1986).

Substrate-borne signals can be emitted by diverse means in subterranean and fossorial rodents: head drumming in Spalax ehrenbergi (Heth et al. 1987, Rado et al. 1987), foot drumming in Bathyergus suillus, B. janetta, Georychus capensis (Bennett and Jarvis 1988), Cryptomys damarensis (Jarvis and Bennett 1991), and 
Dipodomys spectabilis (Randall 1994). Captive blind mole-voles produced substrate-borne signals through repetitive striking of the incisors against the substratum. Nevertheless, it was not clear whether the vibrations were perceived by the subordinate blind mole-vole, directly from the substratum (via incisors or limbs) as suggested by Poduschka (1978), or through a somatosensory mechanism which is independent of the auditory system, such as in Spalax ehrenbergi (Heth et al. 1991, Nevo et al. 1991).

The relative sizes of the acoustic repertoires of the two species described can be compared because they were obtained under similar experimental conditions. Such a comparison shows that the two species of blind mole-voles differed markedly in the size of their repertoire of acoustic signals. M. (T.) gerbei emitted at least 7 types of sounds (including substrate-borne signals and 4 vocal sounds), while $M$. (T.) duodecimcostatus, emitted only 4 types of sounds, with only one vocal sound. However, the types of sounds described here can only be partially compared with published reports of full repertoires of other species (eg Heterocephalus glaber, Pepper et al. 1991), where recordings included many different kinds of interactions like mother-infant communication, etc. This authors reported 12 different types of vocalizations for adult naked mole-rats, and 5 additional ones related to juveniles.

Individuals of both species of mole-voles produced distress sounds in a comparable proportion of encounters, though the great majority of the encounters of $M$. (T.) duodecimcostatus were aggressive while this was not the case in $M$. (T.) gerbei. These apparently contradictory results can perhaps be understood when considering the dominance status of interactions in $M$. (T.) gerbei. Dominance status was determined by the exhibition of freer movements, grooming or other activities that show indifference of the mole-vole toward the opponent (Eisenberg 1968, Kruuk 1972, Colvin 1973, Hinde and Stevenson-Hinde 1976, Cranford and Derting 1983). The emission of distress sounds corresponded in most cases to the subordinate individuals. This relationship between emission of distress sounds and subordinate status was reported by Clarke (1956), Getz (1962), Houseknecht (1968), Novak and Getz (1969), and Turner and Iverson (1973) for Microtus. These authors observed that these sounds were mainly used in a defensive manner by subordinates, and were often effective in inhibiting the approach of the dominant or more active animal.

$M$. (T.) gerbei has a larger repertoire than the other species of mole-voles. Three types of sounds found in this species and not in the $M$. (T.) duodecimcostatus are vocal sounds (greeting sounds, amicable, and tapping). There are, however, some homologous sounds in the two species, two fricative sounds (tooth grinding and throat rasping), a vocal sound (distress sound) and substrate-borne signals. All these sounds were generally associated with the establishment of dominance relationships, and were often part of agonistic interactions. Our observations of the relationship between dominant status and emission of tooth grinding are in agreement with the results of Clarke (1956), Getz (1962), and Novak and Getz 
(1969), for other species of rodents. These authors considered tooth grinding as an aggressive sound frequently produced by the dominant animals in intraspecific encounters. Although both species of mole-voles produced tooth grinding, $M$. (T.) gerbei used this signalling mode rather infrequently. Perhaps this difference may be a consequence of this species being more tolerant to conspecifics than $M$. (T.) duodecimcostatus (aggressive encounters in $M$. (T.) duodecimcostatus were scored in $69 \%$ of the events versus $13 \%$ in $M$. (T.) gerbei). Substrate-borne signals were common in $M$. (T.) duodecimcostatus though rarely observed in $M$. (T.) gerbei. In aggressive encounters involving $M$. (T.) duodecimcostatus, when the individual that perceived the vibrations was aggressive, it reacted to the perception of striking by adopting a defensive posture (the animal stood upright, open-mouthed, forepaws held out to ward off the opponent, Giannoni 1994). In contrast, if the animal did not show signs of aggressiveness, it adopted subordinate postures (sitting hunched, with forepaws leaning against a wall of the chamber, showing the back to the opponent), therefore acting as if scared (Giannoni 1994).

This study suggests that in the most aggressive and less social species, $M$. (T.) duodecimcostatus, substrate-borne signals appear to be more common and the acoustical repertoire is smaller. This species uses these signals extensively in intraspecific encounters and emits only 4 types of sounds. Contrarily, intraspecific encounters of $M$. (T.) gerbei are infrequently aggressive, the animals rarely produce substrate-borne signals, and emit 7 types of sounds. Thus, we can speculate that the emission of substrate-borne signals in mole voles, and probably in subterranean rodents, would be negatively associated with a gradient in the degree of sociability, and positivety associated with the degree of individual dominance and/or aggressiveness. Furthermore, vocal richness would be positively associated with sociability.

Acknowledgments: S. M. Giannoni's research was supported by a Fellowship from the Instituto de Estudios Altoaragoneses (Spain). Sound analyses (by R. Márquez) were funded by project CYCIT PB 89-0045C (P. I. P. Alberch) Ministerio de Educación y Ciencia, Spain. C. E. Borghi was supported by a Fellowship from the CSIC-CONICET scientific agreement between Spain and Argentina. We had the financial support of the project "Erosion in deserted fields" of the Spanish CICYT. We thank J. Bosch and R. Antor-Castellanau for their help in the analyses and field work. P. P. Fernández reviewed an early version of the manuscript. N. Horak assisted with the English version.

\section{References}

Agrawal V. C. 1967. Skull adaptations in fossorial rodents. Mammalia 21: 300-312.

Bennett N. C. and Jarvis J. U. M. 1988. The social structure and reproductive biology of colonies of the mole-rat, Cryptomys damarensis (Rodentia, Bathyergidae). Journal of Mammalogy 69: 293-302.

Borghi C. E. 1992. Los micromamíferos subterráneos del Pirineo Aragonés (Subgénero Pitymys): Impacto sobre la vegetación y papel bioerosivo. Doctoral Thesis, Universidad Autónoma de Madrid, España: 1-167.

Borghi C. E., Giannoni S. M. and Martínez-Rica J. P. 1997. Dispersal of geophytes by mole-voles in the Spanish Pyrenees. Journal of Mammalogy 28 (2). (in press) 
Borghi C. E., Martínez-Rica J. P. and Giannoni S. M. 1991. Quelques donnes nouvelles sur la distribution des rongeurs fouisseurs des Pyrénées d'Aragon (Espagne). Mammalia 55: 445-447.

Burda H., Bruns V. and Müller M. 1990. Sensory adaptations in subterranean mammals. [In: Evolution of subterranean mammals at the organismal and molecular levels. E. Nevo and $\mathrm{O}$. A. Reig, eds]. Alan R. Liss, Inc, New York: 269-293.

Capranica R. R., Moffat J. and Nevo E. 1973. Vocal repertoire of a subterranean rodent Spalax. Abstract from the Annual Meeting of American Acoustical Society, Los Angeles, California.

Chaline J. P., Brunet-Lecomte P. and Graf J. D. 1988. Validation de Terricola Fatio, 1867 pour les Campagnols souterrains (Arvicolidae, Rodentia) paléarctiques actuels et fossiles. Comptes Rendus de l'Académie des Science (Paris), ser. 3, 306: 475-478.

Clarke J. R. 1956. The aggressive behaviour of the vole. Behaviour 9: 1-23.

Colvin D. V. 1973. Agonistic behaviour in males of five species of voles Microtus. Animal Behaviour 21: 471-480.

Cranford J. A. and Derting T. L. 1983. Intra and interespecific behavior of Microtus pennsylvanicus and M. pinetorum. Behavioural Ecology and Sociobiology 13: 7-11.

Dimmint M. A. and Ruibal R. 1980. Environmental correlates of emergences in spadefoot toads (Scaphiopus). Journal of Herpetology 14: 21-29.

Eisenberg J. F. 1968. Behaviour patterns. [In: Biology of Peromyscus (Rodentia). J. A. King, ed]. American Society of Mammalogists, Special Publication No 5: 451-490.

Eisenberg J. F. 1974. The function and motivational basis of Hystricomorph vocalizations. [In: The biology of hystricomorph rodents. I. W. Rowlands and B. J. Wein, eds]. Symposia of the Zoological Society of London: 211-247.

Ferkin M. H. and Rutka T. F. 1990. Mechanisms of sibling recognition in meadow voles. Canadian Journal of Zoology 68: 609-613.

Getz L. L. 1962. Aggressive behavior of the meadow and prairie voles. Journal of Mammalogy 43: 351-358.

Giannoni S. M. 1994. Ecoetología comparada de dos especies de roedores subterráneos: Microtus (Terricola) duodecimcostatus y M. (T.) pyrenaicus. Doctoral Thesis, Universidad Autónoma de Madrid, España: 1-237.

Guédon G., Pascal M. and Mazouin F. 1991a. Le campagnel provençal en captivité (Pitymys duodecimcostatus de Sélys-Longchamps, 1839) (Rongeurs, Microtides). I. La reproduction. Mammalia 55: $97-106$.

Guédon G., Pascal M. and Mazouin F. 1991b. Le campagnol provençal en captivé (Pitymys duodecimcostatus de Sélys-Longcjamps, 1839) (Rongeurs, Microtides). II. La croissance. Mammalia 55: 397-406.

Guédon G., Paradis E. and Croset H. 1992. Capture-recapture study of a population of the Mediterranean pine vole (Microtus duodecimcostatus) in Southern France. Zeitschrift für Säugetierkunde 57: $364-372$.

Hand J. L. 1986. Resolution of social conflicts: dominance, egalitarianism, spheres of dominance, and game theory. Quarter Review of Biology 61: 201-220.

Hartline P. H. 1971. Physiological basis for detection of sound and vibration in snakes. Journal of Experimental Biology 59: 349-371.

Heth G., Frankenberg E. and Nevo E. 1986. Adaptive optimal sound for vocal communication in tunnels of the subteranean mammals (Spalax ehrenbergi). Experientia 42: 1287-1289.

Heth G., Frankenberg E., Raz A. and Nevo E. 1987. Vibrational communication in subterranean mole rats (Spalax ehrenbergi). Behavioural Ecology and Sociobiology 21: 31-33.

Heth G., Frankenberg E. and Nevo E. 1988. "Courtship" call of subterranean mole rats (Spalax ehrenbergi): physical analysis. Journal of Mammalogy 69: 121-125.

Heth G., Frankenberg E., Pratt H. and Nevo E. 1991. Seismic communication in the blind subterranean mole-rats: patterns of head thumping and of their detection in the Spalax ehrenbergi superspecies in Israel. Journal of Zoology, London 224: 633-638. 
Heth G. and Todrank J. 1995. Assessing chemosensory perception in subterranean mole rats: different responses to smelling versus touching odorous stimule. Animal Behaviour 49: 1009-1015.

Hetherington T. E. 1992. Behavioural use of seismic cues by the sandswimming lizard Scincus scincus. Ethology, Ecology and Evolution 4: 5-14.

Hinde R. A. and Stevenson-Hinde J. 1976. Towards understanding relationships: dynamic stability. [In: Growing points in ethology. P. O. Hinde and R. A. Hinde, ed]. Cambridge University Press, New York: 451-479.

Houseknecht C. R. 1968. Sonographic analysis of vocalizations of three species of mice. Journal of Mammalogy 49: 555-560.

Jarvis J. U. M. and Bennett N. C. 1991. Ecology and behavior of the family Bathyergidae. [In: The biology of the naked mole-rat. P. W. Sherman, J. U. M. Jarvis and R. D. Alexander, eds]. Princeton University Press, Princeton, New Jersey: 66-96.

Kruuk H. 1972. The spotted hyena: a study of predation and social behavior. University of Chicago Press, Chicago: 1-340.

Lewis E. R. and Narins P. M. 1985. Do frogs communicate with seismic signals? Science 227: 187-189.

Martínez-Rica J. P., Borghi C. E. and Giannoni S. M. 1995. Estructura de las galerías en tres especies de topillos excavadores de montaña. Historia Natural '93 (España): 329-339.

Mathias M. L. 1989. Preliminary data on the blood properties of pine voles under hypoxic-hypercapnic atmospheric conditions (Arvicolidae, Rodentia). Mammalia 53: 465-467.

Mathias M. L. 1990. Morphology of the incisors and the burrowing activity of Mediterranean and Lusitanian pine voles (Mammalia, Rodentia). Mammalia 54: 302-306.

Mathias M. L. 1991. Adaptations morpho-physiologiques des campagnols aux moeurs endogées. Le Rongeur el l'Espace. Resp. M. Le Berre and L Le Guelte C. R. Chabaud, Paris: 347-352.

Mathias M. L. and Freitas J. P. 1989. Oxigen transport and blood buffering capacity in the Mediterranean pine vole. Miscelania Zoologica 13: 177-180.

Montgomery W. I. 1978. Intra- and interespecific interactions of Apodemus sylvaticus (L.) and A. flavicollis (M.) under laboratory conditions. Animal Behaviour 26: 1247-1254.

Nevo E. 1969. Mole rat Spalax ehrenbergi: mating behavior and its evolutionary significance. Science 163: 484-486.

Nevo E. 1979. Adaptative convergence and divergence of subterranean mammals. Annual Review of Ecology and Systematics 10: 269-308.

Nevo E. 1990. Evolution of nonvisual communication and photoperiodic preception in speciation and adaptation of blind subterranean mole rats. Behaviour 114: 249-276.

Nevo E., Bodmer M. and Heth G. 1976. Olfactory discrimination as an isolating mechanism in speciating mole rats. Experientia 32: 1511-1512.

Nevo E., Heth G., Beiles A. and Frankenberg E. 1987. Geographic dialects in blind mole rats: Role of vocal communication in active speciation. Proceeding of the National Academy of Sciences USA 84: $3312-3315$.

Nevo E., Heth G. and Pratt H. 1991. Seismic communication in a blind subterranean mammal: A major somatosensory mechanism in adaptive evolution underground. Proceeding of the National Academy of Sciences USA 88: 1256-1260.

Novak M. A. and Getz L. L. 1969. Aggressive behavior of meadow voles and pine voles. Journal of Mammalogy 50: 637-639.

Paradis E. and Guédon G. 1993. Demography of a mediterranean microtine: the Mediterranean pine vole, Microtus duodecimcostatus. Oecologia 95: 47-53.

Pepper J. W., Braude S. H., Lacey E. A. and Sherman P. W. 1991. Vocalizations of the naked mole-rat. [In: The biology of the naked mole-rat. P. W. Sherman, J. U. M. Jarvis and R. D. Alexander, eds]. Princeton University Press, Princeton, New Jersey: 243-274.

Pérez-Suárez G., Arévalo F., López-Caballero E. and López-Luna P. 1990. Seasons variations in hematological values and heart weight in two small mammals, a mouse: Apodemus sylvaticus, and a vole: Pitymys duodecimcostatus. Acta Theriologica 35: 201-208. 
Poduschka W. 1978. Abwehrreaktion der Mullratte, Cryptomys hottentotus (Lesson, 1826). Säugetierkundliche Mitteilungen 26: 260-268.

Quilliam T. A. 1966. The mole's sensory apparatus. Journal of Zoology, London 149: 76-88.

Rado R., Levi N., Hauser H., Witcher H., Adler N., Intrator N., Wollberg Z. and Terkel J. 1987. Seismic signalling as a means of communication in a subterranean mammal. Animal Behaviour 35: $1249-1266$.

Rado R., Himelfarb M., Arensburg B., Terkel J. and Wollberg Z. 1989. Are seismic communication signals transmitted by bone conduction in the blind mole rat? Hearing Research 41: 23-30.

Rado R., Wollberg Z. and Terkel J. 1991. The ontogeny of seismic communication during dispersal in the blind mole rat. Animal Behaviour 42: 15-21.

Randall J. A. 1984. Territorial defence and advertisement by footdrumming in bannertail kangaroo rats (Dipodomys spectabilis) at high and low population densities. Behavioural Ecology and Sociobiology 16: 11-20.

Randall J. A. 1994. Discrimination of footdrumming signatus by kangaroo rats, Dipodomys spectabilis. Animal Behaviour 47: 45-54.

Reichman O. J. and Smith S. C. 1990. Burrows and burrowing behaviour by mammals. [In: Current mammalogy. H. H. Genoways, ed]. Plenum Publishing Corp., New York: 197-244.

Salvioni M. 1988. Home range and social behavior of three species of Europen Pitymys (Mammalia, Rodentia). Behavioural Ecology and Sociobiology 22: 203-210.

Siegel S. 1986. Estadística no paramétrica. 2nd ed. Trillas Press, México: 1-344.

Soriguer R. C. 1990. Estructura Social de los Topillos Mediterraneos (Pitymys duodecimcostatus) en las Colonias de las Sierras de Cazorla-Segura. Actas I Congreso Nacional de Etología: 247-256.

Soriguer R. C. and Amat J. A. 1980. On the structure and function of the burrows of the Mediterranean vole (Pitymys duodecimcostatus). Acta Theriologica 25: 268-270.

Stérba O., Hrabém V. and Zima J. 1986. Reproduction in a population of Pitymys subterraneus from Tatras under conditions of high population density. Folia Zoologica 35: 215-228.

Turner B. N. and Iverson S. L. 1973. The annual cycle of aggression in male Microtus pennsylvanicus, and its relation to population parameters. Ecology 54: 967-981.

Vericad J. R. 1970. Estudio faunístico y biológico de los mamíferos del Pirineo. Publicación del Centro Pirenaico de Biología Experimental (CSIC) Vol. 4, Jaca: 1-258.

Wilson D. E. and Reader D. M. (eds) 1993. Mammal species of the world. A taxonomic and geographic reference. 2nd ed. Smithsonian Institution Press, Washington and London: 1-1206.

Zar J. H. 1984. Biostatistical analysis. Prentice-Hall International Editions, New Jersey: 1-718.

Received 24 October 1995, revised 4 December 1996, accepted 15 January 1997. 